\title{
Thoughts on Accounting Standards for Enterprises No.14 - Revenues (Amendment) (Exposure Draft)
}

\author{
Jinming Lai \\ Private Hualian University \\ Guangzhou, China
}

\begin{abstract}
At the beginning of 2015, the Ministry of Finance (MoF) formulated the Accounting Standards for Enterprises No.14 - Revenues (Amendment) (Exposure Draft) for the purpose of regulating the recognition and measurement of the revenues, and the disclosure of the relevant information and then obtaining a substantial convergence between Chinese Accounting Standards (CAS) and the International Financial Reporting Standards (IFRS). This paper provides the author's thoughts on the convergence between Chinese revenue recognition standards into the new international revenue recognition standards by comparing the Exposure Draft and the current Standards.
\end{abstract}

Keywords-revenue standards; changes on standards; thoughts on convergence

\section{THE BACKGROUND OF THE AMENDMENT OF NEW REVENUE RECOGNITION STANDARDS}

In February of 2016, MoF issued the Accounting Standards for Enterprises No.14 - Revenues and the Accounting Standards for Enterprises No.15-Construction Contract for regulating the recognition and measurement of the revenues, and the disclosure of the relevant information. However, the development of market economy and increasingly complicated transactions have posed many problems in the recognition and measurement of revenues, it is therefore pressing for us to reform the recognition and measurement of revenues as defined in the current standards to ensure the problems solving in practice.

In May of 2014, the International Accounting Standards Board (IASB) and the US Financial Accounting Standards Board (FASB) jointly issued the International Financial Reporting Standards No. 15-Revenue from Contracts with Customers (IFRS 15 Revenue from Contracts with Customers), which shall be effective on January 1, 2018 (effective on December 15, 2017 for enterprises that already apply US Generally Accepted Accounting Standards (US GAAP)). The IFRS 15 jointly issued by IASB and FASB specifies new standards for revenues recognition and supersedes the IAS Revenue and IAS Construction Contract.

As there is a conflict between the current standards and economic expansion, and the demand for being in line with the revised international revenues standards, At the beginning of 2015, MoF drafted the Accounting Standards for Enterprises No.14-Revenues (Amendment) (Exposure Draft) (the "Exposure Draft") by adopting the IFRS 15 Revenue from
Contracts with Customers and taking China's actual situation into account.

\section{MODIFICATIONS OF THE NEW REVENUES RECOGNITION STANDARDS}

\section{A. Revenues Recognition Standards}

The current standards specifies that the revenues from selling goods may not be recognized unless the significant risks and rewards of ownership of the goods have been transferred, whereas the revenues generated from providing labor services and by construction contract may be recognized by using the percentage-of-completion method. Therefore, we can see a difference in recognition standards between revenues from selling goods and revenues from construction contract. The current revenue recognition standards distinguishes the revenue recognition standards and construction contract, revenues from selling goods and revenues from providing labor services, total amount and net amount, and defines how to determine whether the significant risk and rewards of ownership of goods have been transferred. However, with the further expansion of market economy ad increasingly complex transactions, the current standards is not applicable for contracts which contain multiple transactions or variable consideration. For example, if the revenue from selling goods and revenue from providing labor services are not identifiable, or not separately measurable despite of identifiable, all of the revenue shall be included in the revenues from selling goods, but doing like this can not reflect an entity' $\mathrm{s}$ actual financial condition.

Since an entity may use different methods to recognize its revenues for certain similar transactions due to its failure to satisfactorily distinguish the current revenue recognition standards and standards for recognizing revenues formed by a construction contract, governmental authority may not accurately evaluate such entity's financial condition and operating performance. To solve this problem, the Exposure Draft is issued to regulate the terms of recognition for revenues from contracts with customers by applying a unified revenue recognition model. The differences, between the Accounting Standards for Enterprises No. 14 - Revenues issued in February of 2006 and the Exposure Draft in revenue recognition, are outlined as below:

Revenues from selling goods may be recognized when the significant risk and rewards of ownership of goods have been transferred and five criteria have been met; 
The revenues from providing the labor services may be recognized in the percentage-of-completion method if an enterprise can, on the date of the balance sheet, reliably estimate the outcome of a transaction concerning the labor services it provides; if the result of a transaction concerning the providing of labor services may not be measured in a reliable way on the date of the balance sheet, and the cost of labor services incurred is expected to be compensated, the revenue from the providing of labor services shall be recognized in accordance with the amount of the cost of labor services incurred, or it is not expected to be compensated, the cost incurred should be included in the current profits and losses, and no revenue from the providing of labor services may be recognized.

The revenues formed by a construction contract may be recognized in the percentage-of-completion method if the outcome of construction contract can be reliably estimated on the balance sheet date; if the outcome can not be estimated in a reliably way and the contract cost is expected to be recovered, the amount of contract cost which is expected to be recovered actually shall be recognized as the revenues formed by construction contract, if the contract cost is not expected to be recovered, no revenues shall be recognized for the construction contract. "Table I"

TABLE I. THE DIFFERENCES OF CURRENT GUIDELINES AND REVISIONS IN REVENUE RECOGNITION AND INCOME METHODS

\begin{tabular}{|c|c|c|c|c|}
\hline \multirow{2}{*}{$\begin{array}{l}\text { Category of } \\
\text { Revenues }\end{array}$} & \multicolumn{2}{|c|}{ Revenue Recognition } & \multicolumn{2}{|c|}{ Recognition Method } \\
\hline & Current Standards & $\begin{array}{c}\text { Revised } \\
\text { Standards } \\
\end{array}$ & Current Standards & Revised Standards \\
\hline $\begin{array}{l}\text { Revenue from } \\
\text { Selling Goods }\end{array}$ & $\begin{array}{l}\text { Revenues from selling goods } \\
\text { may be recognized when the } \\
\text { significant risk and rewards of } \\
\text { ownership of goods have been } \\
\text { transferred and five criteria have } \\
\text { been met }\end{array}$ & \multirow{4}{*}{$\begin{array}{l}\text { A } \\
\text { performance } \\
\text { obligation } \\
\text { satisfied at a } \\
\text { point }\end{array}$} & Five criteria are met simultaneously & \multirow{4}{*}{$\begin{array}{l}\text { Revenues from selling goods } \\
\text { may be recognized when } \\
\text { customer obtains the control of } \\
\text { that products (or services) and } \\
\text { five criteria have been met: } \\
\text { The entity has a present right to } \\
\text { payment for the asset; } \\
\text { The customer has legal title to } \\
\text { the asset; } \\
\text { The entity has transferred } \\
\text { physical possession of the asset; } \\
\text { The customer has the significant } \\
\text { risks and rewards of ownership } \\
\text { of the asset; } \\
\text { The customer has accepted the } \\
\text { asset }\end{array}$} \\
\hline \multirow{3}{*}{$\begin{array}{lr}\text { Revenues } & \text { from } \\
\text { Providing } & \text { Labor } \\
\text { Services } & \end{array}$} & \multirow{3}{*}{$\begin{array}{l}\text { Depending on whether the } \\
\text { outcome of providing labor } \\
\text { services can be reliably } \\
\text { estimated on the balance sheet } \\
\text { date }\end{array}$} & & $\begin{array}{l}\text { If the outcome of providing labor services can } \\
\text { be reliably estimated, the revenue may be } \\
\text { recognized in the percentage-of-completion } \\
\text { method }\end{array}$ & \\
\hline & & & $\begin{array}{l}\text { If the outcome of providing labor services can } \\
\text { not be recognized reliably, however, the cost } \\
\text { of labor services incurred is expected to be } \\
\text { compensated, the revenue shall be recognized } \\
\text { in accordance with the amount of cost of labor } \\
\text { services incurred. }\end{array}$ & \\
\hline & & & $\begin{array}{l}\text { If the result of a transaction concerning the } \\
\text { providing of labor services may not be } \\
\text { measured in a reliable way on the date of the } \\
\text { balance sheet, and the cost of labor services } \\
\text { incurred is not expected to be compensated, } \\
\text { the revenue from the providing of labor } \\
\text { services shall be included in the current profits } \\
\text { and losses, and no revenue from the providing } \\
\text { of labor services may be recognized. }\end{array}$ & \\
\hline \multirow[b]{2}{*}{$\begin{array}{l}\text { Revenues from } \\
\text { Construction } \\
\text { Contract }\end{array}$} & \multirow{2}{*}{$\begin{array}{l}\text { Depending on whether the } \\
\text { outcome of construction contract } \\
\text { can be estimated in a reliably } \\
\text { way on the balance sheet date }\end{array}$} & \multirow{3}{*}{$\begin{array}{l}\text { Performance } \\
\text { obligation } \\
\text { satisfied at a } \\
\text { point }\end{array}$} & $\begin{array}{l}\text { If the outcome can be estimated reliably, the } \\
\text { revenue shall be recognized by using the } \\
\text { percentage-of-completion method }\end{array}$ & \multirow{4}{*}{$\begin{array}{l}\text { 1.If the performance } \\
\text { progress can be measured } \\
\text { reasonably, the revenues shall be } \\
\text { recognized in the percentage-of- } \\
\text { completion method; } \\
\text { 2.If the performance } \\
\text { progress can not be measured } \\
\text { reasonably, the revenue shall be } \\
\text { calculated in the expected cost } \\
\text { plus margin approach. }\end{array}$} \\
\hline & & & $\begin{array}{l}\text { If the outcome can not be estimated in a } \\
\text { reliably way, the amount of contract cost } \\
\text { which can be recovered actually shall be } \\
\text { recognized as the revenues formed by } \\
\text { construction contract }\end{array}$ & \\
\hline \multirow[t]{2}{*}{$\begin{array}{l}\text { Revenue from } \\
\text { Abalienating the } \\
\text { Right to Use } \\
\text { Assets }\end{array}$} & $\begin{array}{l}\text { The relevant economic benefits } \\
\text { are likely to flow into the entity; } \\
\text { and } \\
\text { the amount of revenues can be } \\
\text { measured in a reliable way. }\end{array}$ & & $\begin{array}{l}\text { Interest revenue is recognized in accordance } \\
\text { with the time value of money and actual rate }\end{array}$ & \\
\hline & & & $\begin{array}{l}\text { Revenue shall be recognized based on the time } \\
\text { for charge and approach as agreed in contract } \\
\text { or agreement }\end{array}$ & \\
\hline
\end{tabular}

The Exposure Draft states that an entity shall recognize the revenues when it satisfies a performance obligation by transferring a promised good or service to a customer, which is when the customer obtains control of that good or services. This principle enhances the role of contract and explicitly states the terms of concept and scope of contract, combination of contract and contract modifications. It also states that an entity shall assess the contract on its effective date to identify all performance obligations under that contract and to determine each performance obligation may be satisfied at a point in time or over time. 


\section{B. Revenue Measurement Standards}

An entity may encounter problems, including demand for distinguishing total amount of price and net amount, multiobligation segmentation under more contracts, when applying the current standards to measure the revenues. Therefore, the governmental authority revised the revenue measurement principles in the Exposure Draft by employing two core measurement principles and taking the requirement for convergence towards IFRS 15 - Revenue from Contract with Customers which was jointly issued by IASB and FASB in 2014.

- The method for an entity to recognize its revenues shall reflect the model that entity adopted for transferring its goods and services;

- The revenue measurement shall reflect the consideration an entity has the right to obtain from delivering goods and services.

An entity can apply the below five steps in accordance with the above measurement principles: identify the contract with a customer; identify the performance obligations in the contract; determine the transaction price; allocate the transaction price to the performance obligations in the contract; recognize revenue when the entity satisfies a performance obligation.

1) Identify the contract with a customer: Article 5 of the Exposure Draft states that a contract shall create enforceable obligations and have commercial substance, and emphasizes that a contract must include specific payment terms and the criteria for recognizing the consideration an entity shall be entitled to receive. If a contract does not meet the relevant criteria, the entity shall recognize the consideration received as revenue only when the entity has no remaining obligations to transfer goods or services to the customer and all of the consideration promised by the customer has been received by the entity and is non-refundable, or otherwise, an entity shall recognize the consideration received from a customer as a liability.

2) Identify the performance obligations in the contract: Article 9 of the Exposure Draft states that an entity can identify the transferring of goods or services with the same nature and in the same mode as one performance obligation. Whether the promised goods or services is distinct is a key factor to identify the performance obligation. An entity's obligation to transfer a good or service to a customer is not identifiable if a customer can not use the good or services transferred by the entity when another good or service has not been transferred to that customer. Article 10 of the Exposure Draft provides three factors to separately identify one performance obligation:

An entity does not provide a significant service of integrating the good or service with other goods or services promised in the contract into a bundle of goods or services that represent the combined output for which the customer has contracted.
The good or service does not significantly modify or customize another good or service in the contract;

The good or service is not highly dependent on, or highly interrelated with, other goods or services promised in the contract.

As can been seen from the above, Article 10 of the Exposure Draft gives the factors to determine whether the goods or services promised in the contract is identifiable but provides no specific standards and scope. Therefore, an entity can identify its performance obligation reflecting the commercial substance of transaction by using its professional judgment.

3) Determine the transaction price: Article 14 of the Exposure Draft defines the transaction price as an amount of consideration to which an entity expects to be entitled in exchange for transferring promised goods or services to a customer. The factors to be considered when determining the amount of consideration include: variable consideration, consideration payable to customers, non-cash consideration, the existence of a significant financing component in the contract.

As set forth in Article 16 of the Exposure Draft, the variable consideration shall be the amount an entity expects to obtain or most possibly obtains with the below limitations: an entity shall include in the transaction price some or all of an amount of variable consideration to the extent that it is highly probable that a significant reversal in the amount of cumulative revenue recognized will not occur when the uncertainty associated with the variable consideration is subsequently resolved.

If an entity shall pay a customer (or the third party who purchases the entity's goods or services from the customer) the consideration, the consideration payable to the customer shall be accounted for as a reduction of the transaction price. The entity shall recognize the reduction when the entity recognizes relevant revenue or the entity pays or promises to pay the consideration to a customer, whichever is later.

Non-cash consideration. An entity shall determine the transaction price at the fair value of non-cash consideration. If an entity cannot reasonably estimate the fair value of the non-cash consideration, the entity shall measure the consideration indirectly by reference to the stand-alone selling price of the goods or services promised to the customer. The fair value of non-cash consideration shall be considered as variable consideration if it varies for other than form of the consideration.

The contract contains a significant financing component if an entity shall determine the transaction price based on amount payable by a customer and to be paid in cash upon a customer obtains the control of goods or services. The difference between the transaction price and the contract consideration shall be allocated based on the actual interest rate during the contract term.

4) Allocate the transaction price to the performance obligations in the contract: According to Article 20 of the 
Exposure Draft, to allocate the transaction price to each performance obligations in the contract, an entity shall determine the stand-alone selling price for goods or services promised in the contract. The best evidence of a stand-alone selling price is the observable price of a good or service when the entity sells that good or service separately in similar circumstances and to similar customers. If a standalone selling price is not directly observable, an entity shall estimate the stand-alone selling price by taking all relevant information that is reasonably available for the entity and employing suitable methods, including adjusted market assessment approach, expected cost plus a margin approach, residual approach. The entity shall begin to allocate the transaction price as of the effective date of the contract and shall not re-allocate the transaction price due to the change on stand-along selling price from the effective date of the contract.

\section{ThOUGHTS ON THE NEW REVENUES RECOGNITION STANDARDS}

Pursuant to the Exposure Draft, the revenues shall be recognized when customer obtains the control of that products or services promised in the contract rather than when the significant risk and rewards of ownership of goods have been transferred as defined in the original standards; the revenues shall be recognized subject to the performance obligation which has been actually performed; the revenues recognized shall reflect the amount of consideration an entity shall be entitled to obtain from delivering the goods or services promised in the contract. The Exposure Draft applies five-step measurement principles to recognizing revenues, which effectively increases the comparability of application of revenue recognition and measurement practice in multiple industries, cross-enterprises and capital market.

The standards for recognition and measurement of revenues as revised in the Exposure Draft have different impact on different enterprises and industries. It has small impact on goods distribution and retailing transactions, but has significant impact on accounting treatment of long-term contract which involves multiple transactions mainly involving asset management, building and construction, real estate and telecommunications, etc.

\section{REFERENCES}

[1] Ma Xuanling. Accounting Measurement Principles Analysis on the Exposure Draft of Revenue Recognition Standards [J] New Accounting, 2016 (8).

[2] Wei Jing. Changes of International Revenues Recognition Standards and Its Impact [J]. Communication of Financial and Accounting, 2016 (25).

[3] Wang Qiliang. Comparisons between the Accounting Standards for Enterprises No.14 - Revenues (Amendment) (Exposure Draft) and the current standards [J]. Accounting Reformation and Innovation, 2016 (8).

[4] Fu Dandan. Research on the Accounting Concept of Revenues Recognition Standards Issued by IASB [J]. Communication of Financial and Accounting, 2016 (3).
[5] Li Xintong. Thoughts on the Convergence of Chinese Revenues Recognition Standards into the New International Revenues Recognition Standards [J]. Chinese Township Enterprises Accounting, $2016(10)$. 